\title{
Titel/Title: Professionalised Representation of Human Rights NGOs to the United Nations
}

Autor*innen/Author(s): Kerstin Martens

Veröffentlichungsversion/Published version: Postprint

Zeitschriftenartikel/Journal article

\section{Empfohlene Zitierung/Recommended citation:}

Martens, Kerstin (2006): Professionalised Representation of Human Rights NGOs to the United Nations. In: International Journal of Human Rights, 10 (1), 19-30.

Verfügbar unter/Available at:

(wenn vorhanden, bitte den DOI angeben/please provide the DOI if available)

This is an Accepted Manuscript of an article published by Taylor \& Francis in International Journal of Human Rights on 08.08.2006, available online:

https://doi.org/10.1080/13642980500386081

Zusätzliche Informationen/Additional information:

The author can be contacted at:

martensk@uni-bremen.de 
Professionalised Representation of Human Rights NGOs to the United Nations

Kerstin Martens

\section{ABSTRACT}

Most studies explain the rise of NGOs as actors on the international stage by emphasising political developments or technical achievements as factors which have fostered their success. The focus in this paper, instead, will be on how NGOs themselves have transformed and how such change has affected the way in which they have become significant players in international relations. Drawing upon the notion of professionalisation as deriving from theoretical approaches of societal activism, I argue that NGOs increasingly invested in their international presence and gradually professionalised. In order to illustrate the argument, professionalisation of NGO representation to the UN will be examined with respect to four case studies of international human rights organisations: Amnesty International, Human Rights Watch, the International Federation of Human Rights and the International League for Human Rights.

\section{INTRODUCTION $^{1}$}

Over the last decade, non-governmental organisations (NGOs) have become important players in international relations ${ }^{2}$. In particular, since their participation during the series of world conferences in the first half of the 1990s, they have increasingly been recognised as significant actors on the international scene. In the years to follow, they constantly gained greater access to the forums of intergovernmental organisations (IGOs), such as the United Nations (UN). As a result, NGOs today are basically involved in all processes and performances of the UN. In the human rights sector, for example, they deliver valuable information and profound research on human rights violations to $\mathrm{UN}$ commissions and committees, they provide knowledge and expertise during negotiation processes of international human rights law and declarations, and they monitor and supervise the implementation of human rights standards and principles.

\footnotetext{
${ }^{1}$ A special "thank you" goes to my research assistant Celia Enders for editing the article and preparing it for publication.

${ }^{2}$ In this paper, NGOs are understood as international, independent and formal societal actors. NGOs are societal actors because they are established by private initiative. They are international and consist of individuals and local, regional and national member organisations. NGOs are also independent because they are primarily sponsored by membership fees and private donations; however, they may receive funding from the state, but they are not under the control of governmental institutions. Moreover, NGOs are formal organisations, since they have - at the least - a basic organisational structure which allows them to provide for continuous work. This includes a headquarters, permanent staff and a constitution. For a detailed discussion of current interpretations of the term NGO, see K. Martens, "Mission Impossible? Defining Nongovernmental Organizations", Voluntas, Vol.13, No.3 (2002), pp. $271-85$.
} 
Scholars from various disciplines explored the growing significance of NGOs in international relations and sought to explain the reasons why they have considerably gained in importance and reputation. Risse and contributors, for example, explored the conditions under which non-state actors, such as NGOs, have an impact on international relations ${ }^{3}$. Along such lines, Keck and Sikkink identified a boomerang pattern by which advocacy networks bypass state blockages by forming alliances with $\mathrm{IGOs}^{4}$. Developing $(\leftarrow$ p. 19) such concepts even further, Risse, Ropp and Sikkink set up the spiral model which shows the consequent steps of how non-governmental organisations exercise influence on norm-violating states ${ }^{5}$. By focusing on changing circumstances in which NGOs operate, such accounts and approaches provide significant evidence for the increasing influence of NGOs in the international arena. Most importantly, scholars, in this respect, highlight political developments and technical achievements which enabled NGOs to have greater options for participating in international relations. In particular, the end of the Cold War as the significant political incident and the rise of new means of communication (email and internet) are stressed as having had tremendous impact on the growing importance of $\mathrm{NGOs}^{6}$.

In this paper, I will take a different perspective and draw attention to how NGOs themselves have transformed over time. With such an approach, I seek to explore the extent to which such changes, too, may have contributed to the way in which NGOs operate in international relations and why they have progressively become more important. To illustrate the argument, I will focus on how NGOs increasingly invested in their international presence and gradually professionalised their representation to intergovernmental forums. The idea of this paper thus is that changing external factors are necessary, but only one condition for NGOs to be able to interact on the international scene. Internal organisational developments, however, provide an additional factor which contributed to the rise of NGOs and explain their increasing participation in international affairs.

${ }^{3}$ T. Risse-Kappen (ed.), Bringing Transnational Relations Back In: Non-State Actors, Domestic Structures and International Institutions (Cambridge: Cambridge University Press 1995).

${ }^{4}$ M. Keck and K. Sikkink, Activists Beyond Borders (Ithaca, NY: Cornell University Press 1998).

${ }^{5}$ T. Risse, S. Ropp and K. Sikkink (eds), The Power of Human Rights. International Norms and Domestic Change (Cambridge: Cambridge University Press 1999).

${ }^{6}$ J. Boli and G. Thomas (eds), Constructing World Culture: INGOs Since 1875 (Stanford, CA: Stanford University Press 1999); D. della Porta, H. Kriesi and D. Rucht (eds), Social Movements in a Globalizing World (Chippenham: St. Martin's 1999); R. Lipschutz, "Reconstructing World Politics: The Emergence of Global Civil Society", Millennium, Vol.21, No.3 (1992), pp. 389 - 420; J. Smith, R. Pagnucco and W. Romeril, "Transnational Social Movement Organisations in the Global Political Arena", Voluntas, Vol.5, No.2 (1994), pp. 121 - 54; C. Warkentin, Reshaping World Politics. NGOs, the Internet, and Global Civil Society (Lanham, MD: Rowman and Littlefield 2001); P. Wapner, "Governance in Global Civil Society", in O. Young (ed), Global Governance: Drawing Insights from the Environmental Experience (Cambridge, MA: MIT Press 1997), pp. 65 - 84; J. Smith, C. Chatfield and R. Pagnucco (eds), Transnational Social Movements and Global Politics. Solidarity beyond the State (Syracuse, NY: Syracuse University Publication 1997). 
As the theoretical base, the study applies resource mobilisation theory of social movement organisations since professionalisation is firmly associated with this approach $^{7}$. For the empirical part, the professionalisation of NGOs at UN level regarding the protection and promotion of human rights is chosen since this is a policy field in which NGOs are particularly active. Four prominent human rights organisations have been selected for deeper study: Amnesty International, Human Rights Watch, the International Federation of Human Rights and the International League for Human Rights. For all four cases of human rights NGOs, the different stages and phases, prospects and limits of professionalising their representation to the United Nations will be examined. In order to acquire data, semi-standardised expert interviews with NGO representatives and UN staff members have been conducted, as well as NGO material has been examined ${ }^{8}$.

\section{SOCIETAL ACTIVISM AND THE NOTION OF PROFESSIONALISATION}

The different steps in increasing interaction between societal actors and official institutions are a subject with a long tradition in social research. A frequently cited approach in this context is the Weber-Michels model about the effects of such relations on social movements. In these classic approaches, attention has been drawn to the changes in the organisational structures and resulting performance when social movements are gradually becoming more involved in the political process. The central line of argument in such accounts is that due to the growing size of the movement, its increased participation in society, and its intensified interaction with the official actors, the movement needs to establish organisational structures in order to keep up with the greater demands for co-ordination. These internal changes, such as the division of labour, administrative structures and professional leadership, are necessary processes to ensure the ongoing success of the

\footnotetext{
${ }^{7}$ Suzanne Staggenborg, "The Consequences of Professionalization and Formalization in the Pro-Choice Movement”, in D. McAdam and A. Snow (eds), Social Movements: Readings on their Emergence, Mobilization, and Dynamics (Los Angeles, CA: Roxbury 1997), pp. $421-39$.

${ }^{8}$ Interview partners included: Andrew Clapham, Amnesty Representative in New York 1991 - 97 (by email, 3 May 2001); Anne Burke, temporary Amnesty Representative in New York 2000 - 2001 (New York, 8 February 2001); Daniel Perez-Llebot, UN Department of Economic and Social Affairs, New York (New York, 18 April 2001); Eleni Petroula, Representative of the International Federation of Human Rights 1998 - 2001 in Geneva (Geneva, 5 December 2000); Martin Macpherson, Amnesty Head of Legal Office, London Amnesty International Secretariat (London, 21 June 2001); Melinda Ching, Amnesty Representative in Geneva (Geneva, 4 December 2000); Raymonde Martineau, UN NGO Liaison Service in Geneva (Geneva, 4 December 2000); Sara Guillet, Representative of the International Federation of Human Rights in Geneva 1994 - 98 (Paris, 14 June 2001); Nigel Rodley, Amnesty Head of Legal Office, London Amnesty International Secretariat 1973 - 90 (New York, 21 March 2001); Joanna Weschler, Human Rights Watch Representative in New York (New York, 27 February 2001); Wilder Taylor, Human Rights Watch Legal and Policy Director, London Office (London, 4 December 2001); Loubna Freih, Human Rights Watch Representative in Geneva (Geneva, 30 May 2002); Alexei Korotayev, Representative of the International League for Human Rights in Geneva (Geneva, 7 December 2000); Catherine Fitzpatrick, Representative of the International League for Human Rights in New York - 2002 (by email, 21 June 2001).
} 
movement. As a consequence, however, the main objective of the organisation becomes its own consolidation, and bureaucratic functions prevail over ideological considerations. $(\leftarrow$ p. 20)

Building upon such models, other scholars further concentrated on examining the relation between organisational structures of societal actors and the effects on their modes of interaction. Most importantly, resource mobilisation theorists developed approaches to explore the conditions under which societal actors adapt to their changing environment. They observed that achievements of societal actors depend on their capacities to mobilise resources for their activities ${ }^{9}$. Unlike classic social movement approaches, however, resource mobilisation theory is not fatalistic about an unavoidable declining ideological base of societal activism, rather, this approach seeks to specify the conditions under which processes of change take place. Scholars of such approaches therefore focus on examining organisational structures of societal actors and argue that such internal processes are important factors which determine the performance of the organisation in relation to official actors.

An important feature which has since been emphasised in this respect is the notion of professionalisation ${ }^{10}$. Professionalisation describes the process whereby problems are increasingly dealt with by persons with relevant subject-specific knowledge, experience and training, rather than by staff members solely recruited for their previous political activism or engagement in the organisation. Rucht and Roose, for example, refer to professionalisation as recruiting "members with special training relevant to their role in the group"11. Similarly, Brand views the process of professionalisation as the increasing acquirement of necessary expertise such as subject knowledge and academic training ${ }^{12}$. Correspondingly, Diani and Donati provide a case from the environmental sector where staff is recruited with experience in communication and journalism, and a background in science and law $^{13}$.

For others, instead, professionalisation refers less to conditions for the recruitment of staff, rather it is the creation of a profession out of a position which had previously been conducted on a voluntary basis. For Meyer and Tarrow, for example, professionalisation means that part-time activists become full-time movement professionals ${ }^{14}$. Both ways, however, professionalisation aims at routinising processes

\footnotetext{
${ }^{9}$ J. McCarthy and M. Zald, "Resource Mobilization and Social Movements: A Partial Theory", in M. Zald and J. McCarthy (eds), Social Movements in an Organizational Society (New Brunswick, NJ: Transaction 1987), pp. $15-42$.

${ }^{10}$ Staggenborg (note 6).

${ }^{11}$ D. Rucht and J. Roose, “The German Environmental Movement at a Crossroad?", Environmental Politics, Special Issue: Environmental Movements - Local, National and Global, Vol.8, No.1 (1999), p. 78.

${ }^{12}$ K.-W. Brand, "Dialectics of Institutionalisation: The Transformation of the Environmental Movement in Germany", Environmental Politics, Special Issue: Environmental Movements - Local, National and Global, Vol.8, No.1 (1999), pp. 40 and 47.

${ }^{13}$ M. Diani and P. Donati, "Organisational Change in Western European Environmental Groups: A Framework for Analysis", Environmental Politics, Special Issue: Environmental Movements - Local, National and Global, Vol.8, No.1 (1999), p. 20.

${ }^{14}$ D. Meyer and S. Tarrow, "A Movement Society: Contentious Politics for a New
} 
and at maintaining or increasing quality standards in the work of the organisation in order to make it more effective and efficient in contributing and shaping political process $\mathrm{e}^{15}$. That is to say, as a consequence, professionalising an organisation affects its maintenance, strategies and tactics ${ }^{16}$.

Applied to NGOs and their relationship with the UN, the process of professionalisation thus encompasses the appointing of personnel to represent the organisation in the context of the intergovernmental organisation. It refers to organisational provisions, such as the establishment of NGO offices in UN locations or the setting up of a special section within the international headquarters of an NGO dedicated to its relations with the UN. It also takes account of the number of people working on the NGO's UN-related matters, in the international headquarters as well as at offices in UN locations. Moreover, the individual educational and professional background of those people representing their NGOs to the UN, the significance of their experience and knowledge of the UN system to their recruitment, as opposed to prior involvement with the NGO, are indicators of professionalisation. Differences in the degree to which organisations professionalise, however, depend on their organisational composition. In resource mobilisation theory, it has been argued that unitary organisations are more effective at mobilising resources than organisations with a rather federative structure ${ }^{17}$. In the international arena, NGOs differ by how their national components relate to the international body. Unitary NGOs consist of dependent member organisations and maintain central decision-making structures. Moreover, they $(\leftarrow$ p. 21) have a clear division of labour and a large body of staff. Due to such organisational structures, they are able to operate quickly, effectively and efficiently ${ }^{18}$. In addition, they have the structural and organisational capacities to invest significant resources in a specific project, such as their representation to the UN. Federative NGOs, instead, consist of autonomous member organisations and maintain decentralised decision-making structures. Moreover, they usually have only a small body of staff which takes over diverse functions ${ }^{19}$. For such reasons, federative NGOs have only limited means to be invested into their representation to the UN.

Amnesty International and Human Rights Watch, for example, are international unitary NGOs. They consist of dependent national member sections which are guided by a powerful international headquarters ${ }^{20}$. National sections of Amnesty

Century", in D. Meyer and S. Tarrow (eds), The Social Movement Society (Lanham, MD: Rowman and Littlefield 1988), p. 16.

${ }^{15}$ D. Rucht, B. Blattert and D. Rink, "Soziale Bewegungen auf dem Weg zur Institutionalisierung. Zum Strukturwandel alternativer" Gruppen in beiden Teilen Deutschlands (Frankfurt: Campus 1997), p. 55.

${ }^{16}$ Staggenborg (note 6) p. 421.

${ }^{17}$ C. Jenkins, "Resource Mobilization Theory and the Study of Social Movements", Annual Review of Sociology, Vol.9 (1983), p. 539.

${ }^{18}$ D. Young, "The Structural Imperatives of International Advocacy Associations", Human Relations, Vol.44, No.9 (1991), pp. 921 - 41; D. Young, "Organising Principles for International Advocacy Associations”, Voluntas, Vol.3, No.1 (1991), pp. 1 - 28.

${ }^{19}$ Ibid.

20 "Amnesty International is the most centralised. Decision-making authority is concentrated at the international secretariat level in Amnesty International rather than at the national level. This again reflects the nature of Amnesty International's issue focus and aims. 
and Human Rights Watch prepare their local activities by themselves, but they need to act in conformity with the object and mandate of the international organisation. Moreover, both NGOs have a comparatively significant budget at their disposal and maintain a large body of staff. In contrast, the Federation and the League are loose federations of autonomous national member organisations. Each national organisation decides on its programme of work independently of its international federative body. The international headquarters are fairly small and mainly facilitate communication between the members.

Applying such concepts in this study, depending on the type of NGO, differences in the degree of professionalised relations with the UN are likely. According to such approaches, unitary NGOs are more likely to professionalise than federative NGOs because they can devote more resources to relations with IGOs. They have better capacities to set up and professionalise positions for their interaction with the UN. Federative NGOs, instead, have only rather limited means for their UN representation. Therefore, Amnesty International and Human Rights Watch are more likely to mobilise resources and professionalise their UN representation than the International Federation of Human Rights and the International League for Human Rights.

\section{PROFESSIONALISATION OF NGO REPRESENTATION TO THE UN - GEN- ERAL OBSERVATIONS}

\section{THE IMAGE OF NGO REPRESENTATIVES IN THE PAST}

For a long time, NGO representation to the $\mathrm{UN}$ had predominantly been conducted by volunteers who had only little professional affiliation with their organisation ${ }^{21}$. In early studies, NGO representatives are described as "volunteers, retired, or representing their organizations in their spare time"22. They were associated with the image of "little old ladies in tennis shoes" 23 or "politicians on the downward slope" 24 , whose work "seemed confined to collecting documents and attending meetings", while others "come just for the ride, with expenses paid". Only a few delegates showed up for attending sessions to hear oral statements by NGO representatives, while others read newspapers ${ }^{25}$.

As a result, until the 1980s, in most cases, representation to the UN was still more a source of status, prestige, and ego-satisfaction for individuals rather than an additional opportunity for NGOs to exert influence on the UN system. Many of those

In order to provide accurate and reliable information that is effective in pressuring for international human rights protection, Amnesty International must enforce strict standards for information-gathering and dissemination". Smith et al. (note 5) p. 134.

${ }^{21}$ E. Bock, Representation of Non-Governmental Organizations and the United Nations (Public Administration Clearing House 1955).

22 A. Archer, "Methods of Multilateral Management: The Interrelationship of International Organizations and NGOs", in G. Trister (ed.), The US, the UN and the Management of Global Change (New York, NY: UNA-USA 1983), p. 303.

${ }^{23}$ Ibid.

${ }^{24}$ P. Chiang, Non-Governmental Organizations at the United Nations. Identity, Role and Functions (New York, NY: Praeger 1981), p. 235.

${ }^{25}$ Ibid. 
early persons "representing" an NGO at the UN are described as simply enjoying having access to important people, such as international diplomats, UN officials and governmental representatives. They were able to meet them in the lounges, chat with them, and have coffee or lunch in the UN cafeteria together. As a result, discussions were "rarely rising above the purely social kaffee klatsch level". Because of such low calibre, relations $(\leftarrow \mathbf{p . ~ 2 2})$ with NGOs were often regarded as ineffective, and many secretariat and governmental delegates did not take NGO representation at the $\mathrm{UN}$ seriously ${ }^{26}$.

However, as Chiang - an observer of the NGO/UN relationship in that period recognised, an increased professionalisation of NGO representatives could improve the reputation of NGO representatives and the poor relations between NGOs and the UN. "NGO relations undoubtedly will improve to the extent the quality of NGO representatives at the UN rises. Upgrading their quality will necessarily involve a search for representatives with expertise and sophistication, but also with a knowledge both of the organisation they present, its history, purpose, and politics, and of the purpose and functions of NGOs, historically, politically, and philosophically, vis-à-vis the governments and IGOs such as the UN. Coupled with an understanding of the changes occurring daily in the world, in international politics and at the UN, such NGO representatives may well serve their role as initiators and participants in a continuing dialogue involving the various communities of the world, both within and outside the $\mathrm{UN}^{27}$.

Over the years, indeed, NGOs increasingly recognised the potential of their activities with the UN and gradually invested in their international representation. Many NGOs shifted from being voluntarily represented at the UN to having professional representatives conducting their international presence. For example, some NGOs nominated a regular staff member to conduct all the affairs of the organisation with the UN. Other NGOs divided up their representation and those staff members who, in their daily work, had dealt with specific subject matters took over the representation of the organisation at $\mathrm{UN}$ level when such issues were on the agenda. Some NGOs even decided to establish independent offices in major UN locations and devoted professional full-time personnel to their representation.

\section{GROWING REPUTATION OF HUMAN RIGHTS NGOS}

In the human rights sector, such shifts led to greater recognition of the capacities of NGOs. Representatives of human rights NGOs were gradually invited to participate in UN commissions and committees, due to their legal expertise as well as their technical skills ${ }^{28}$. In particular, they were increasingly valued for their knowledge and their provision of assistance in the development of human rights standards. As a result, "human rights NGOs seem on the verge of being offered the prospect of becoming 'insiders', working through and with the UN to achieve what has not been possible or desirable for them in the past - the delivery of

\footnotetext{
${ }^{26}$ Ibid. p. 328.

${ }^{27}$ Ibid. p.244.

${ }^{28}$ H. Schmitz, "Nichtregierungsorganisationen und internationale Menschenrechtspolitik", Comparativ, Vol.7, No.4 (1997), p. 53.
} 
legal services"29.

In particular, various informal mechanisms between human rights NGOs and UN bodies have been developed over the course of the 1990s, through which NGO representatives can be impressively influential. For example, representatives of human rights NGOs are often invited by the High Commissioner for Human Rights today to feed in their information. In particular, before a mission of the High Commissioner to a country, NGO representatives are sometimes asked at short notice to give a briefing on the country's human rights situation. Moreover, representatives of human rights NGOs are also regularly invited to consultations with UN Security Council members. Sometimes on a weekly basis, NGO representatives meet with high-ranking delegates to inform and $(\leftarrow \mathbf{p}$. 23) discuss current issues and problems in a small and limited forum, known as the "NGO Working Group on the Security Council’"30.

In fact, the growing professionalisation of NGO representatives working at UN level also led to increasing job exchanges between NGOs and the UN: NGO staff shifted to UN jobs and vice versa. As Weschler reports for the human rights sector: "[b]esides, owing to their long existence, non-governmental organisations have by now created a sizable group of human rights professionals. When at the beginning of the 1990s, the United Nations for the first time needed within a fairly short period of time a relatively large number of properly prepared staff to fill many human rights posts in peacekeeping operations, and then in human rights field operations, NGOs became the main source of experts, both at the rank-andfile and the managerial levels" ${ }^{\prime 1}$.

Moreover, NGO representatives are increasingly regarded as responsible and experienced partners, because they are not being changed on any routine practice. UN officials, instead, often lack the necessary knowledge, since they have to change their location and tasks, as their profession involves rotation between different posts $^{32}$. Thus, officials seek contact with NGO representatives, because "they know that such contacts usually bring in as a result reliable materials and helpful analyses"33.

\section{TOTAL NUMBER OF NGO REPRESENTATIVES TO THE UN}

Today, the total number of NGO representatives and their position within the organisation they are representing and the intensity with which they make use of their representational functions is not statistically reported. In fact, official statistics about NGOs and their representatives only exist to a limited extent. Although the

\footnotetext{
${ }^{29}$ F. Gaer, "Reality Check: Human Rights Nongovernmental Organisations confront Governments at the United Nations", in T. Weiss and L. Gordenker (eds), NGOs, the UN, and Global Governance (Boulder, CO: Lynne Rienner 1996), p. 60.

${ }^{30}$ Global Policy Forum, "A Short History of the NGO Working Group on the Security Council”, available online at: http://www.globalpolicy.org/security/ngowkrp/history.htm (accessed 12 March 2004).

${ }^{31}$ J. Weschler, "Non-Governmental Human Rights Organizations", Polish Quarterly of International Affairs, Vol.7, No.3 (1998), p. 154.

${ }^{32}$ Ibid. p. 153.

${ }^{33}$ Ibid.
} 
UN demands that NGOs nominate their representatives each year, the IGO only keeps limited track of these records. For administrative reasons, the UN requires accredited NGOs to nominate at least one "liaison person" of their organisation who can be contacted by the UN for all administrative purposes. The status of those persons within the NGOs, however, is not officially registered in any UN document and may vary from volunteers to regular NGO staff members to fulltime professional NGO representatives.

An NGO, however, can nominate up to 15 different representatives, five in each of the major UN locations with NGO liaison offices (New York, Geneva and Vienna). Moreover, for special events, such as international conferences, NGOs are able to nominate additional representatives, sometimes without any upper limit. NGOs often exhaust their contingent of representatives so that various people, even though they do not represent the NGO on a regular basis, are allowed to enter UN buildings without bureaucratic hurdles. Moreover, for the same administrative reasons, one or two of these positions are often reserved for the president and the secretary-general of the NGO, even though s/he might be coming in rarely, and often only for special occasions in order to represent their NGO.

\section{MOBILISING RESOURCES FOR THEIR REPRESENTATION TO THE UN - CASE STUDIES}

\section{ORGANISATIONAL PROVISIONS FOR NGO REPRESENTATION}

Professionalised representation to the $\mathrm{UN}$ gradually became an issue of increasing importance for human rights NGOs. Amnesty International's representation in New York, for $(\leftarrow$ p. 24) example, was first led by local members from the city. They started the "office" in a private home in the early 1970s and represented the $\mathrm{NGO}$ at the UN in their spare time. Fairly early on, however, the NGO recognised that its interaction with the $\mathrm{UN}$ bodies in charge of human rights required more work than could be handled by volunteer members or Amnesty International's staff flying in from London for special occasions only. When in the late 1970s the human rights discourse advanced significantly, Amnesty sought to increase the opportunities for advancing human rights at UN level and decided to invest more resources in maintaining its international presence.

In 1977, its representation in New York changed from being led voluntarily to becoming fully provided with professional staff members. Over that time, the number of professional representatives was increased, and today three full-time staff members represent the NGO in New York. Moreover, Amnesty has also been represented in Geneva for many years. From the early 1980s, the organisation held a post there which had been led by a local Amnesty member. In 1988, this position, too, became an integral part of Amnesty's representation to the UN and was equipped with a full-time paid representative ${ }^{34}$. Today, Amnesty maintains an office in Geneva with two people working exclusively on relations with the UN and during the six-week session of the Commission on Human Rights their work is

\footnotetext{
${ }^{34}$ H. Cook, "Amnesty International at the United Nations", in P. Willetts (ed.), "The Conscience of the World". The Influence of Non-Governmental Organisations in the UN System (London: Hurst 1996), p. 185.
} 
supported by staff from London.

Human Rights Watch, too, designated people to work exclusively on UN matters. Since 1994, there have been two people working on the NGO's relations with the $\mathrm{UN}$, forming a separate unit in its headquarters in New York City. In addition, the NGO has also been represented in Geneva by a volunteer since 2000. This position, too, became professionalised only one year later. Before Human Rights Watch was represented in Geneva by local staff, the New York representative had commuted between both UN locations. She had gone to Geneva about five times a year to represent Human Rights Watch in meetings and sessions. Most importantly, she had spent a considerable period of time there during the sessions of the Commission.

In addition to its posts in New York and Geneva, Amnesty International also maintains staff members in its international headquarters who work almost entirely on relations with the UN. The NGO's programme on "Legal and International Organisations", for example, provides legal advice for the NGO, originates and supervises the design of documents, and also leads and guides Amnesty's work with intergovernmental organisations. As part of this programme, one staff member works on the special mechanisms of the UN and another two staff members deal with questions concerning the treaty bodies. Similarly to Amnesty International, Human Rights Watch, too, has other staff members who are deeply involved concerning the NGO's work with the UN. In addition to its representation in major UN locations, Human Rights Watch maintains a Legal and Policy Department based in London which deals with UN-related matters and legal affairs.

The Federation and the League also invested in their UN representation. Compared to Amnesty International and Human Rights Watch, however, they had only limited resources for such posts. The office of the Federation in Geneva started in the early 1990s and was first led by a volunteer doing his community service (in lieu of military service). In 1994, the NGO decided to make this post a full-time paid position. The UN bodies in New York, instead, were run by a volunteer representative until 1999, but this position is now vacant. Similarly, the International League for Human Rights has been represented in Geneva since 1998. A volunteer who operates on a "grant basis" represents the League whenever it is necessary.

\section{$(\leftarrow$ p. 25)}

Unlike Amnesty and Human Rights Watch, there is no specific section or person in the international headquarters of the Federation in Paris working on relations with the UN only. However, the NGO's chief administrator takes over the representation of the organisation at key moments and, for example, goes to Geneva for three or four days during the session of the Commission on Human Rights. Moreover, a representative from the Federation's international headquarters visits the UN in New York from time to time when a major event is taking place. In the League's international headquarters in New York, all staff members spend time on UN-related activities, but the organisation maintains no designated staff member working exclusively on the NGO's relations with the UN. 
The professional experience and the educational background of the recruits to represent the NGOs at the UN play an increasingly important role. Amnesty International's professional representatives at the UN, for example, are highly skilled people with specific training necessary for their positions. They have gone through higher educational programmes and hold post-graduate degrees. Most of them have studied law as a first degree, others a subject or course with an international focus, such as international relations or development studies. Moreover, of the most recent having held or holding the post of Amnesty's representatives, the majority of them have an LLM degree in international law. An increasing number even specialise in international human rights studies.

Although such a legal background is not formally required, it is desirable because of the nature of the work as Amnesty's UN representative. As mentioned in an interview, Amnesty representatives do not necessarily have to be lawyers, but due to the work of the NGO at the UN and the experience and knowledge needed for this job, "it happens to be in most cases people trained in jurisprudence" who represent Amnesty before the UN. A former Amnesty representative in New York in the 1990s also emphasised the importance of his legal training, as his work on UN peacekeeping and the International Criminal Court "was very legal". Similarly, staff members of Amnesty's Legal and International Organisations Programme, based in London, are also generally trained in legal or international studies and usually have some years of experience in working with legal matters.

Likewise, for the position of Human Rights Watch's representatives to the UN, educational and professional training are decisive factors for recruitment. The Geneva representative, for example, has a strong background in journalism which is highly valued since she intensively and regularly has to deal with the media. Especially her negotiation skills, acquired as part of her post-graduate degree in public administration, are often of great help. Moreover, she took several specialised courses in human rights as it became "vital" - as she expressed it - to have such technical skills for her job as Human Rights Watch representative to the UN.

In addition, experience with the UN machinery is highly desirable as a qualification for the post as representative. Amnesty International's representatives at the $\mathrm{UN}$, for example, are required to know the system and mechanisms of the UN system well, since this knowledge is necessary to make significant use of the intergovernmental machinery for Amnesty's goals and to develop appropriate strategies for campaigning and action. As Cook of Amnesty explains, "in order to make an impact, it is important for an NGO to $(\leftarrow$ p. 26) send delegates with a real grasp of the issue and with expertise in drafting and, as far as possible, to maintain continuity in its delegates, building on their familiarity of the issue, the process and the other players involved" ${ }^{35}$.

Whereas educational background and a knowledge of the UN system are extremely important, prior involvement with Amnesty is not a precondition for the post as its representative at the UN. In fact, most professional representatives had not been actively involved with the NGO before taking up the position as its UN representative. Only rarely have Amnesty's representatives gained some sort of 
experience on the local level with letter-writing, and this has generally not been the important factor in their recruitment. In addition, none of the representatives has had experience with working for the NGO in the International Secretariat. Instead, new recruits receive some training by attending a general introduction to Amnesty's work in London. Thus, representative work for Amnesty at UN level is, as mentioned in an interview, basically "training on the job".

As with Amnesty, for the post as the representative of the Federation at the UN knowledge about legal affairs concerning human rights has become increasingly necessary. The different people who have been representing the Federation in Geneva studied law as a first degree and specialised in Human Rights Law through Master's degrees. Moreover, knowledge of the UN system and the human rights mechanisms was an essential criteria in their recruitment. Similar to Amnesty, experience in groundwork for the NGO is not considered as important as educational background. Neither the representatives of the Federation nor those of the League in Geneva have worked for the NGO before taking up the post. Instead, they have had general experience in working for human rights organisations.

\section{CONCLUDING REMARKS}

In this paper, organisational factors for explaining NGO activity at the international level have been the subject of analysis. For this reason, professional NGO representation at the $\mathrm{UN}$ has been explored in its theoretical dimension and on some empirical cases. In the theoretical section, professionalisation has been highlighted as a possible additional explanatory factor for NGO activity at UN level. For the empirical part of this study, four cases of NGOs in the field of human rights protection have been selected for intense study. The examples of Amnesty International, Human Rights Watch, the International Federation of Human Rights and the International League for Human Rights have been examined and explored. Their individual relationship with the $\mathrm{UN}$ has been retraced over time in order to extract patterns, similarities and differences in how they professionalised their representation to the IGO.

All in all, the picture of NGO representation to the UN has shifted over the last decades. Whereas in the 1980s NGOs and their representatives were still often regarded as amateurish, since the 1990s they have gained in recognition due to their professional appearance and their subject-specific expertise. On the four examples of human rights NGOs it was shown that organisations recruit highly qualified and skilled professionals with substantial knowledge about the subject matter to represent them at the UN. As argued in the theoretical section of this paper, such organisational developments should also be taken into account when explaining the rise of NGOs in international affairs.

However, in accordance with the theoretical accounts of resource mobilisation theory presented in this study, there are also some differences in the degree of professionalized $(\leftarrow \mathbf{p}$. 27) relations with the UN, depending on the particular type of NGO. Unitary NGOs are more likely to professionalise than federative NGOs because they can devote more resources to their relations with IGOs. Due to their organisational structure, they have better capacities to set up offices in major UN 
locations and increase the number of staff representing them than federative NGOs which only have limited means to devote to their UN representation.

The examples chosen for deeper study in this paper have shown such differences. Whereas the four organisations do not vary by the factors for recruiting their representatives, namely educational background and professional experience, there are differences in the amount of resources NGOs are able to dedicate to their representation to the UN. That is to say, all cases of NGOs recruit their representatives primarily for reasons of expertise and experience; however, Amnesty International and Human Rights Watch have greater means to devote to representation to the UN than the Federation and the League, which need to rely on voluntary representation.

In sum, the evidence of the cases in this study - although carefully selected and representing typical cases - can only be an initial step which provides some first insights on the issues. In addition to this explorative study which highlights several aspects of the professionalisation of NGOs, further research (quantitative surveys, for example), are needed for delivering even more wide-ranging findings. 